\title{
The protective effects of adalimumab on intestinal injury induced with infrarenal aortic occlusion
}

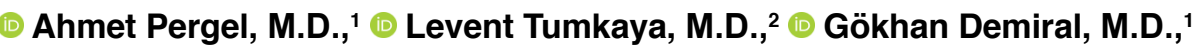 \\ Muhammet Kadri Çolakoğlu, M.D., ${ }^{1}$ \ Süleyman Kalcan, M.D., ${ }^{\circledR}$ Ali Özdemir, M.D., \\ D Tolga Mercantepe, M.D., ${ }^{2}$ @ Başar Erdivanlı, M.D., ${ }^{3}$ ๑ Adnan Yılmaz, M.D. ${ }^{4}$
}

\begin{abstract}
${ }^{1}$ Department of General Surgery, Recep Tayyip Erdoğan University Faculty of Medicine, Rize-Turkey
${ }^{2}$ Department of Histology and Embryology, Recep Tayyip Erdoğan University Faculty of Medicine, Rize-Turkey

${ }^{3}$ Department of Anesthesia and Reanimation, Recep Tayyip Erdoğan University Faculty of Medicine, Rize-Turkey

${ }^{4}$ Department of Biochemistry, Faculty of Medicine, Recep Tayyip Erdoğan University Faculty of Medicine, Rize-Turkey
\end{abstract}

\begin{abstract}
BACKGROUND: The present study aims to observe the effects of ischemia-reperfusion (IR) on small intestines at a molecular level and to prospectively assess the potential preventive role of adalimumab (ADA) and antioxidants.

METHODS: A total of 24 male Sprague-Dawley rats were randomly divided into three groups-a control group, an IR group and an IR+ADA group.

RESULTS: Although there was no change in SOD levels in the small bowel tissue of the IR group, we observed increased malondialdehyde (MDA) levels and increased numerical density of caspase- 3 and TNF- $\alpha$ positive enterocytes $p=0.00$ and $p=0.00$, respectively). We also observed that IR caused the degeneration of villus crypt structures.

CONCLUSION: We found that ADA treatment reduced MDA levels and decreased the numerical density of caspase- 3 and TNF- $\alpha$ positive enterocytes compared to the IR group $(p=0.00 ; p=0.01 I ; p=0.00$, respectively). We conclude that $A D A$ can be beneficial in preventing intestinal injury that arises from IR.
\end{abstract}

Keywords: Adalimumab; intestinal injury; ischemia; oxidative stress; rat; reperfusion.

\section{INTRODUCTION}

Intestinal ischemia-reperfusion (IR) injury, seen after various surgical and clinical situations, such as thoracoabdominal aortic surgery, liver transplantation, intestinal transplantation, strangulated hernias, acute mesenteric ischemia, shock, trauma, and neonatal necrotizing enterocolitis, is an important clinical problem that causes approximately $50-80 \%$ of all deaths in surgical intensive care units after major traumas. ${ }^{[1,2]}$ The small intestine is one of the most ischemia-sensitive organs. ${ }^{[3,4]}$ Occlusion of the infrarenal abdominal aorta may also cause ischemic injury, and cell and tissue damage may also occur in remote organs due to complex mechanisms involv- ing, for example, reactive oxygen species (ROS), neutrophil infiltration, and the release of inflammatory mediators when reperfusion is achieved. ${ }^{[5,6]}$ ROS cause cellular damage by negatively affecting antioxidant defense mechanisms by reducing Superoxide dismutase (SOD) levels and increasing malondialdehyde (MDA) levels. ${ }^{[7]}$ The most important mediator that initiates the inflammatory process in IR injury is thought to be tumor necrosis factor-alpha (TNF- $\alpha) \cdot{ }^{\left[{ }^{[8]}\right.}$ The effects of TNF on IR injury have not been fully explained, but it has been shown that TNF is the most important factor in apoptosis. ${ }^{[8,9]}$ In addition, recent studies have shown that ROS cause DNA damage and lead to caspase-dependent apoptosis. ${ }^{[0,11]}$ In recent studies, intestinal IR has been reported to increase

Cite this article as: Pergel A, Tumkaya L, Demiral G, Çolakoğlu MK, Kalcan S, Özdemir A, et al. The protective effects of adalimumab on intestinal injury induced with infrarenal aortic occlusion. Ulus Travma Acil Cerrahi Derg 2020;26:366-372.

Address for correspondence: Ahmet Pergel, M.D.

Recep Tayyip Erdoğan Üniversitesi Tıp Fakültesi, Genel Cerrahi Anabilim Dalı, 53010 Rize, Turkey

Tel: +90 464 - $2130491 \quad$ E-mail: tolgamercantepe@yahoo.com

Ulus Travma Acil Cerrahi Derg 2020;26(3):366-372 DOI: 10.14744/tjtes.2019.59607 Submitted: 26.03.2019 Accepted: 24.06.2019 Online: I5.05.2020

Copyright 2020 Turkish Association of Trauma and Emergency Surgery 
caspase- 3 activation, an irreversible terminal event in the activation of apoptosis. However, some studies have reported that TNF- $\alpha$ blockers suppress inflammation that arises from TNF- $\alpha$ and eliminate free oxygen radicals (scavengers). ${ }^{[12,13]}$ Other studies have found that anti-TNF-a, when given prophylactically has a protective, effect that reduces IR injury. [14,15] After the TNF inhibitors infliximab and etanercept, adalimumab (ADA) - approved by the Food and Drug Administration for clinical use in treating rheumatoid arthritis, psoriatic arthritis, ankylosing spondylitis, Crohn's disease, moderate to severe chronic psoriasis, and juvenile idiopathic arthritis-is the first anti-TNF- $\alpha$ monoclonal antibody obtained from humans. $^{[16,17]}$

In light of this information, we studied the effects of infrarenal aortic IR on the small intestine at the molecular level. Following, we discuss the possible prophylactic potential of ADA and antioxidants

\section{MATERIALS AND METHODS}

\section{Animals}

Twenty-four Sprague-Dawley male rats $(250 \pm 50 \mathrm{~g}$ and 3-5 months old) were used in the present study. All animals were fed and maintained at 55-60\% humidity and $22 \pm 2{ }^{\circ} \mathrm{C}$ room temperature in laboratory animal unit, which is lightened for 12 hours and darkened for 12 hours at University's Faculty of Medicine Basic Medical Sciences Experimental Animals Application Unit. All animals received humane care according to the criteria outlined in the 'Guide for the Care and Use of Laboratory Animals' prepared by the National Academy of Sciences and published by the National Institutes of Health. This study was approved by the University Animal Ethical Committee (ID: 2015/19).

\section{Experimental Groups}

A total of 24 male Sprague-Dawley rats were randomly divided into three groups. Control group $(n=8), I R(n=8)$ and IR+ADA $(n=8)$. ADA (Humira; Abbott, Abbott Park III, 40 mg/0.8 mL) was intraperitoneally administered as $50 \mathrm{mg} / \mathrm{kg}$ (single dose) after being diluted with saline five days before I/R.

\section{The Technique of Intestinal I/R}

Before ischemia-reperfusion, animals were given only water for the last 12 hours. For anesthesia, $50 \mathrm{mg} / \mathrm{kg}$ intraperitoneal (i.p.) Ketamine hydrochloride (Ketalar ${ }^{\circledR}$, Parke-Davis), and $10 \mathrm{mg} / \mathrm{kg}$ i.p. xylazine $\mathrm{HCl}\left(\right.$ Alfaz $^{\circledR}$, Alfasan International B.V., Woerden, The Netherlands) were administered. The rats were placed in the supine position under a heating lamp. The abdominal skin was shaved, washed with an antiseptic solution, and a midline cross-section was performed. The intestines were carefully pulled to the left to reveal the abdominal aorta. The atraumatic microvascular clamp was placed in the abdominal aorta under the level of the renal artery. After making sure that there was no pulsation in the distal aorta, the skin was closed to prevent heat and fluid loss. The skin area was approximated with a suture following the administration of warm saline to peritoneal cavity to prevent loss of abdominal fluid after the clamp procedure. To perform arterial pressure monitoring, the right carotid artery was connected to the monitor with a transducer set and the invasive pressure monitoring was continued during the experiment. One hour after the ischemia, the clamp was opened and the pulse was controlled at distal aorta and reperfusion was allowed for I hour. ${ }^{[18-20]}$ An only midline laparotomy was performed on the animals in the control group. Blood samples were taken with Median sternotomy for biochemical analysis from the right ventricle of all animals. For histopathological examination, ileal segments were excised and stored under appropriate conditions.

\section{Biochemical Investigations \\ Preparation of Homogenates}

The small intestine tissue samples were cold phosphate buffer was added 2 times the volume tissue weight and homogenized for $30 \mathrm{~min}$. Homogenized intestinal tissues samples were centrifuged at $3000 \mathrm{~g}$ for 15 minutes.

\section{SOD Analysis}

The activity of SOD was measured using colorimetric assay kit (Cayman Chemical Company, Michigan, USA). The procedure for the assay method was according to the instructions provided by the manufacturer. Absorbance was measured at a wavelength of $450 \mathrm{\eta m}$ using plate reader. The activity of SOD is presented as $\mathrm{U} / \mathrm{ml}$. The intra-assay and inter-assay coefficient of variation were $3.2 \%$ and $3.7 \%$, respectively. The dynamic range for the SOD assay kit was $0.025-0.25 \mathrm{U} / \mathrm{ml}$.

\section{The MDA Analysis}

MDA levels were measured by the double heating method of Draper and Hadley.* The principle of the method is the spectrophotometric measurement of the color generated by the reaction of thiobarbituric acid (TBA) with MDA. The MDA levels are presented as micromol/L. ${ }^{[21]}$

\section{Histopathological Analysis Procedure}

The small intestine tissue removed from the rats in all groups was washed with phosphate buffer ( $\mathrm{pH}$ : 7.4; Sigma-Aldrich, Germany) and then fixed in 10\% phosphate-buffered formalin for 36 hours. After fixation, the specimens of the small bowel tissue were implanted in paraffin (Merck Darmstadt, Germany) blocks after routine histological follow-up. Samples of the small intestine were sectioned with a microtome device (Leica RM2525, Lecia, Germany) with a thickness of 3-4 $\mu \mathrm{m}$. Sections were stained with Harris hematoxylin and Eosin $G$ (H \& E; Merck, Darmstadt, Germany). Sections under a light microscope (Olympus BX5I, Olympus Corp. Japan) were analyzed. The findings observed in the photos were taken with the digital camera (Olympus DP20, Olympus Corp. Japan). 
Immunohistochemistry (IHC) Analysis Procedure

Following steps were performed for Caspase 3 and TNF- $\alpha$ staining: the sections were deparaffinized and treated with proteinase $\mathrm{K}$ solution $(20 \mu \mathrm{g} / \mathrm{mL}$ in PBS), washed in distilled water and immersed in $3 \%$ hydrogen peroxide. After several washes with PBS, the sections were immersed in an equilibration buffer. Sections were incubated with primary antibody (Caspase 3,I:200, Abcam Rabbit polyclonal to active Caspase-3, UK) and TNF- $\alpha$ (Caspase 3,1:200, Abcam Rabbit polyclonal to active Rabbit polyclonal to TNF- $\alpha$, UK). After several washes, all sections were incubated in anti-digoxigenin-peroxidase then incubated with $0.06 \%$ 3,3-diaminobenzidine tetrahydrochloride (DAB, Sigma Chemical, St. Louis, $\mathrm{MO}$ ) in PBS. Eventually, sections were counter-stained with Harris hematoxylin (Merck, Darmstadt, Germany). ${ }^{[22]}$

\section{The Semi-quantitative Analysis}

In this study, intestinal damage grade scores Chiu et al. ${ }^{[23]}$ methods were calculated using the Olympus DP2-BSW (Ver.2.I to Ver.2.2, Build 6212, Tokyo, Japan) software system was used. H\&E stained sections were put on the microscope tray, and their sectional boundaries were determined using this program. After determining the area, frames separated from each other were determined by histopathologist random (Table I).

\section{Stereological Analysis}

The mean IHC positive cell numerical density was calculated using the fractional method, of the Stereo Investigator (MicroBrightField 9.0, Colchester, VT, CA, USA) software system was used. IHC stained (Caspase- 3 and TNF- $\alpha$ ) sections were put on the microscope tray, and their sectional boundaries were determined using this program. After determining the area, frames separated from each other were determined

Table I. Grading score of the mucosal damage (Chiu et al.)

Grade The sequence of morphological changes

$0 \quad$ Normal mucosal villi.

I Development of subepithelial Gruenhagen's space, usually at the apex of the villus; often with capillary congestion.

2 Extension of the subepithelial space with moderate lifting of epithelial layer from the lamina propria.

$3 \quad$ Massive epithelial lifting down the sides of villi.

A few tips may be denuded.

$4 \quad$ Denuded villi with lamina propria and dilated capillaries exposed. Increased cellularity of the lamina propria may be noted.

5 Digestion and disintegration of lamina propria; hemorrhage and ulceration. by systematic random sampling of the sections, according to the rules of space fragmentation with the step interval of the $x$ and $y$-axis. Then, in 40 different selected areas, of all groups were measured following the method described by Mercantepe. ${ }^{[24]}$

\section{Statistical Analysis}

Statistical analysis of the SOD and MDA of all groups was performed using SPSS (IBM SPSS Statistics 18.0, IBM Corporation, Somers, NY, USA). Differences between the groups were tested using one-way analysis of variance (ANOVA) followed by a Tukey HSD test; the numerical data of groups were analyzed ( $\mathrm{P}$-value $<0.05$ was selected as significant). The values were determined as means \pm standard deviation.

\section{RESULTS}

\section{Biochemical Results}

The effects of adalimumab on intestinal SOD and the MDA levels are shown in Table 3. There were statistically non-significant $(p>0.05)$ decreases in the SOD level in the group treated with $I / R$ as compared with the control and I/R+Ada groups. I/R significantly increased the MDA level when compared with the control group $(p<0.05)$. Adalimumab administration significantly decreased the MDA level when compared with the I/R group $(p<0.05)$. There were statistically nonsignificant $(p<0.05)$ in the MDA level in the group treated

Table 2. Biochemical analysis results

\begin{tabular}{|c|c|c|}
\hline \multirow[t]{2}{*}{ Groups } & MDA level (micromol/L) & SOD level $(\mathrm{U} / \mathrm{ml})$ \\
\hline & (Mean士SD) & $($ Mean \pm SD) \\
\hline Control $(n=8)$ & $3.65 \pm 0.54$ & $30.22 \pm 5.27$ \\
\hline$I / R(n=8)$ & $5.07 \pm 0.66^{\mathrm{a}}$ & $29.09 \pm 4.64$ \\
\hline$I / R+A D A(n=8)$ & $3.89 \pm 0.50^{b}$ & $28.06 \pm 3.40$ \\
\hline
\end{tabular}

${ }^{a} \mathrm{P}=0.00$ versus control group; ${ }^{\mathrm{b}} \mathrm{P}=0.00$ versus $\mathrm{I} / \mathrm{R}$ group.

SD: Standard deviation; IR: Ischemia-reperfusion; ADA: Adalimumab; MDA: Malondialdehyde; SOD: Superoxide dismutase.

Table 3. The mucosal changes following a period of the ischemia/reperfusion are graded

\begin{tabular}{lc}
\hline Group & \begin{tabular}{c} 
Damage grade score \\
\cline { 2 - 2 }
\end{tabular} \\
\hline Control $(n=8)$ & $0.00 \pm 0.13$ \\
I/R $(n=8)$ & $5.00 \pm 0.00^{\mathrm{b}}$ \\
I/+ADA Group-treated group $(n=8)$ & $2.00 \pm 00.35^{\mathrm{b}, \mathrm{c}}$
\end{tabular}

${ }^{\mathrm{D}} \mathrm{P}<0.05$ versus to Control group. $\mathrm{P}<0.05$ versus to Ischemia/ Reperfusion group. Based on the Kruskal-Wallis test. SD: Standard deviation; IR: Ischemiareperfusion; ADA: Adalimumab. 
Table 4. Caspase-3 positive numerical density measurement $\left(\mathrm{mm}^{3}\right)$ data

\begin{tabular}{lccc}
\hline Group & Caspase-3 positive nume rical density & & TNF- $\alpha$ positive numerical density \\
\cline { 2 - 3 } & (Mean $\pm S D)$ & (Mean $\pm S D)$ \\
\hline Control $(n=8)$ & $4.00 \pm 2.27$ & $6.75 \pm 3.85$ \\
l/R $(n=8)$ & $39.00 \pm 13.06^{\mathrm{a}}$ & $64.87 \pm 18.33^{\mathrm{a}}$ \\
l/R+ADA Group-treated group $(n=8)$ & $17.63 \pm 6.48^{\mathrm{b}}$ & $14.50 \pm 7.3^{\mathrm{c}}$ \\
\hline
\end{tabular}

${ }^{a} \mathrm{P}=0.00$ versus to Control group; ${ }^{\mathrm{P}} \mathrm{P}=0.01 \mathrm{I}$ versus to $\mathrm{I} / \mathrm{R}$ group; $\mathrm{C}=0.00$ versus to $\mathrm{I} / \mathrm{R}$ group. Tukey HSD test.

SD: Standard deviation; IR: Ischemia-reperfusion; ADA: Adalimumab; TNF- $\alpha$ : Tumor necrosis factor alpha.

with adalimumab as compared with the control. In brief, the group treated with Adalimumab, the SOD activity statistically nonsignificant increased than I/R group, and the MDA level activity decreased than I/R group (Table 2 ).

\section{Light Microscopy Results}

Light microscopic sections obtained from the intestinal tissue of the control group showed normal histological structural features. The level of damage for samples taken from the control group was evaluated as 0 (normal mucosa, according to Chiu et al.) (Figs. Ia; Table 4). The intestinal tissue of the ischemia group was widely loss in epithelial cells and ulceration. In addition, ischemia group samples showed the disintegration of the lamina propria with hemorrhage and Crypts of Lieberkuhn degeneration. The degree of structural damage in the ischemia group intestinal tissue samples is five (disintegration of lamina propria, hemorrhage, and ulceration)
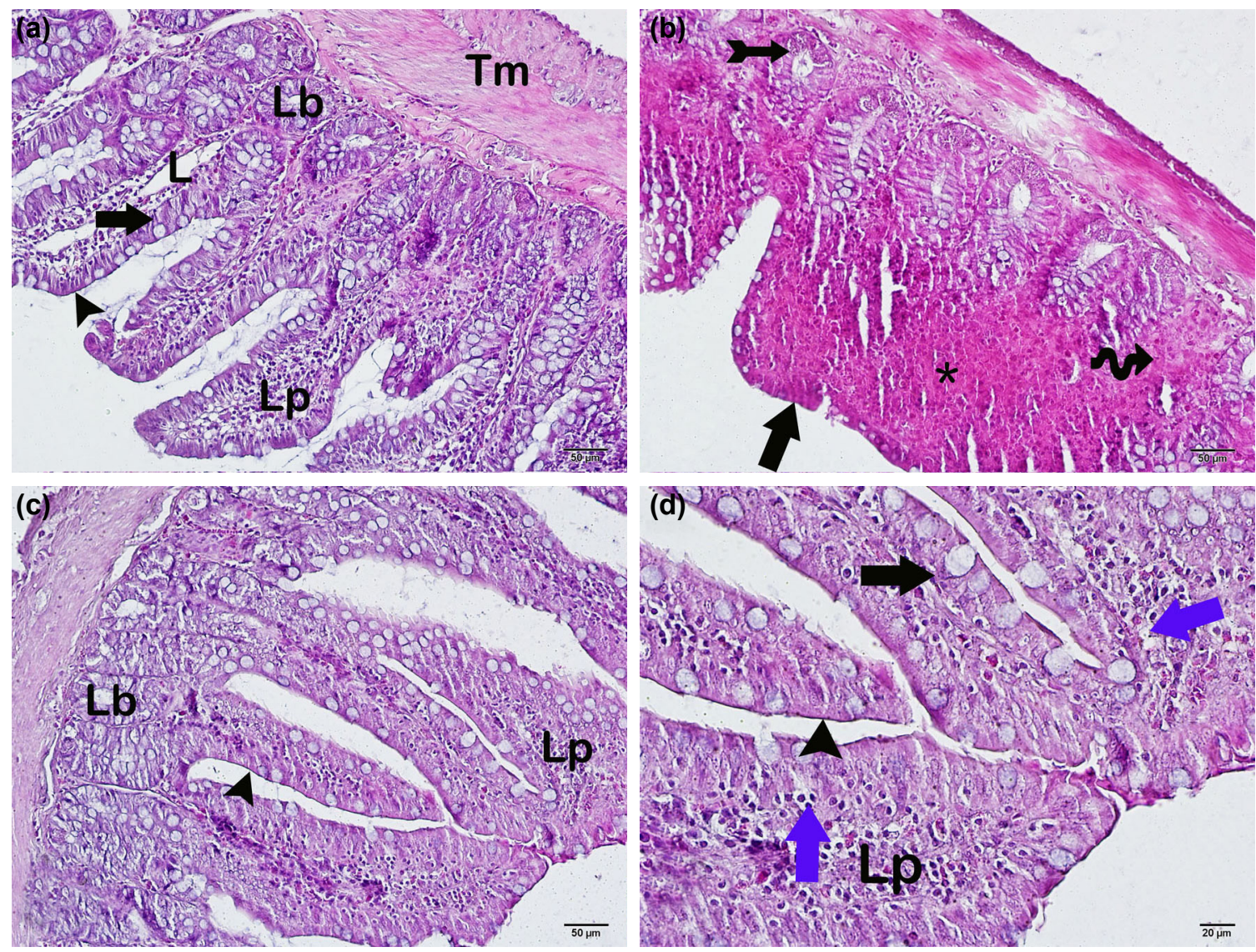

Figure 1. Histology of the small intestine in ischemia damage. H\&E. (a) Control group: damage grade score 0; Healthy morphological and intact structures of the mucous membrane (arrow). Crypts of Lieberkuhn (Lb). Lamina propria (Lp). Tunica muscularis (Tm). (x20). (b) Ischemia Group: damage grade score 5; Ischemia group samples showed the disintegration of the lamina propria (spiral arrow), hemorrhage (asterisk) and ulceration (arrow). Crypts of Lieberkuhn degeneration (tailed arrow). (x20). (c) Ischemia+Ada Group: damage grade score 1; Intact structures of the mucous membrane (arrow). Crypts of Lieberkuhn (Lb). Lamina propria (Lp). (x20). (d) Ischemia+Ada Group; Mucous membrane (arrow). Development of subepithelial (Gruenhagen) spaces near the tips of the villi. (x40). 
(Figs. Ib; Table 4). In the ischemia/reperfusion + adalimumab group-treated group, intact structures of the mucous membrane were regularly. However, the development extension of the subepithelial space with moderate epithelial lifting from the lamina propria. The degree of structural damage in the I/R+ADA Group-treated group's small intestine varies between 2 (2, an extension of the subepithelial space with moderate epithelial lifting from the lamina propria) (Figs. Ic, d) (Table 3).

\section{Immunohistochemical (IHC) Results}

We found that the I/R administration significantly increased the numerical density of caspase- 3 and TNF- $\alpha$ positive intestinal epithelial cells compared to the control group $(p=0.00$, $p=0.00$; respectively). However, we found that the numerical density of Caspase- 3 and TNF- $\alpha$ positive intestinal epithelial cells in the ADA treatment group was significantly lower than that of the I/R group ( $p=0.011, p=0.00$; respectively) (Table 4; Figs. 2, 3).

\section{The Semi-quantitative Analysis}

The results also revealed a high level of damage score for sample measurement of the ischemia/reperfusion group (Score: $5)$ compared to the control group (score: 0$)(p=0.00)$. The I/R+ ADA Group-treated group showed a decreased level of damage score (Score: 2) for sample measurement than the ischemia/reperfusion group (Score: 5) $(p=0.00)$ (Table 3; Fig. I).

\section{DISCUSSION}

There are many studies on the arteries that directly feed the small intestines, particularly the mesenteric arteries, and IR studies have shown that $I R$ results in a weakened intestinal villus structure, leukocyte infiltration, and hemorrhage of the subepithelial connective tissue. In addition, various studies investigating the indirect effects of IR on the small intestine using abdominal aortic clamping have found that IR is the result of the loss of villus epithelia. ${ }^{[25,26]}$ In the present study, we observed intestinal ulceration due to intestinal epithelial loss. We also observed hemorrhage and the degeneration of intestinal crypts in subepithelial connective tissue.

The research has not fully explained the mechanism involved in IR damage to tissue; however, IR has been reported to increase the amount of ROS, resulting in lipid peroxidation. ${ }^{[18,19]}$ Ohkawa et al. ${ }^{[27]}$ reported that MDA levels in intestinal tissues are an index of lipid peroxidation. Cuzzocrea et al. ${ }^{[28]}$ found that IR increased intestinal MDA levels. Zhan et al. ${ }^{[29]}$ found that IR decreased superoxide dismutase (SOD) levels. Although we observed that IR increased SOD levels in our study, we did not observe a statistically significant difference. In this context, we found that infrarenal IR increased the level of intestinal oxidants but did not observe any effects of IR on the antioxidant enzyme SOD.

Various studies have reported that abdominal and intestinal IR induces apoptosis in intestinal cells in addition to in-
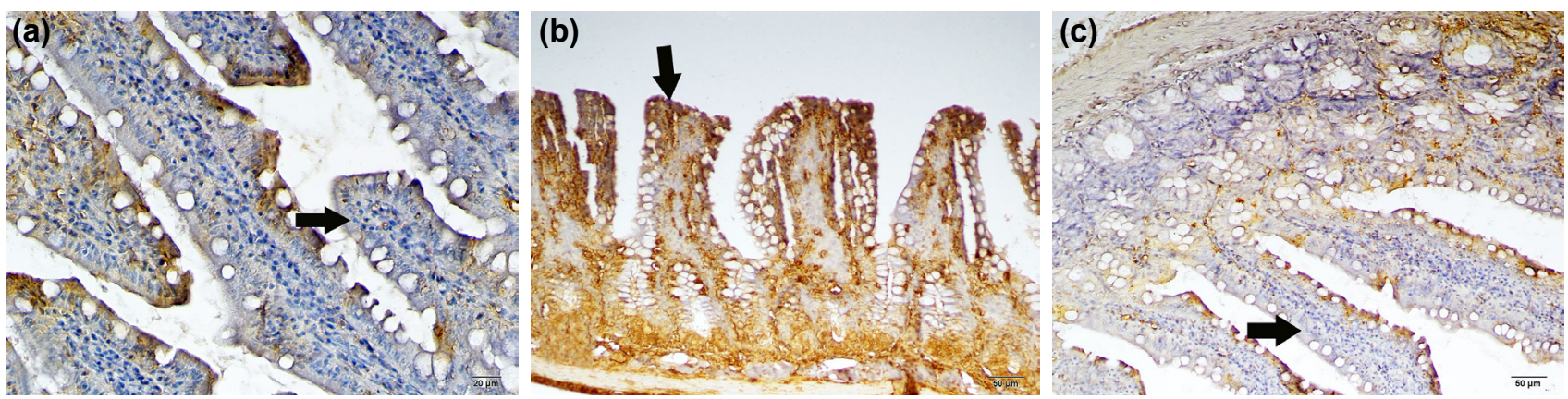

Figure 2. Immunohistochemical staining with the immunoperoxidase method and histopathologic examination of the small intestine under the light microscope. (a) Control group. x40. (b) Ischemia group. x20. (c) Ischemia+Ada treated group, immunoperoxidase staining with the anti-caspase-3 antibody. x20.
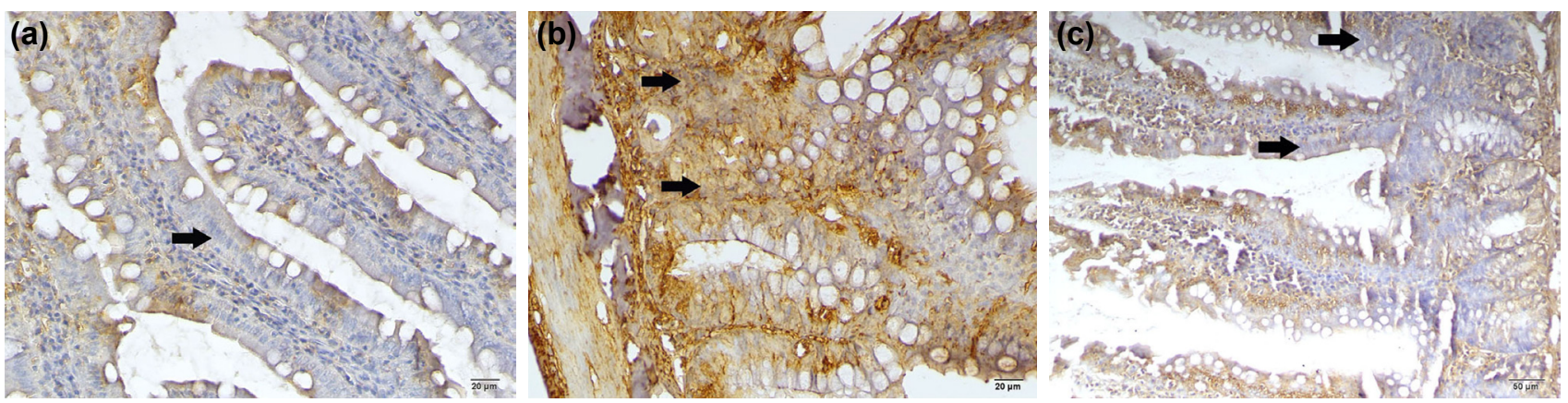

Figure 3. TNF- $\alpha$ Immunohistochemical staining with the immunoperoxidase method and histopathologic examination of the small intestine under the light microscope. (a) Control group. x40. (a) Ischemia group. x40. (c) Ischemia+Ada treated group. 
creasing ROS. Sun et al. ${ }^{[30]}$ found that intestinal IR induces multiple organ failure, causing apoptosis and oxidative stress. The activation of caspase- 3 is considered to be both an irreversible terminal stage of apoptosis and a marker of apoptosis. Gordeeva et al. ${ }^{[3]}$ reported that IR increased caspase-3 levels in their study. In our study, we found that IR caused the apoptosis of enterocytes.

The pro-inflammatory cytokine TNF- $\alpha$ has been found to induce oxidative stress in recent studies. ${ }^{[32,33]}$ Neirynck et al. ${ }^{[32]}$ reported that it increased the production of free oxygen radicals. Another study investigated the suppressive effects of TNF- $\alpha$ inhibitors on the pro-inflammatory and pro-oxidative effects of TNF- $\alpha$ and on IR. ${ }^{[18]}$ The present study demonstrated that adalimumab inhibited IR-induced inflammation by decreasing TNF-alpha expression. In addition, Cure et al. ${ }^{[20]}$ employed the abdominal aorta clamping method in investigating why ADA decreased oxidative stress in their study of IR. Kurt et al. employed the infrarenal abdominal aorta clamping method in their study of IR and found that ADA lowered MDA levels. ${ }^{[19]}$ Shen et al. ${ }^{[34]}$ found that ADA reduced apoptosis in their study. Ossendorff et al. ${ }^{[35]}$ reported that ADA reduced caspase-3 expression. Similarly, we found that ADA reduced the IR-induced apoptosis of enterocytes.

There are some limitations to our study. Regarding oxidative stress, it should be evaluated in conjunction with other oxidants and antioxidant enzymes and molecules in relation. In addition, the level of intracellular calcium and free oxygen radicals must be assessed vis-à-vis apoptosis.

The results of this study indicate that oxidative stress is caused by lipid peroxidation induced by infrarenal abdominal IR. We observed ulceration due to the apoptosis of enterocytes and enterocyte loss in villi. However, we did not observe any effects on SOD, an IR antioxidant enzyme. We found that ADA reduces lipid peroxidation and apoptosis, thus reducing $I R$ damage to the small intestine. This study could be useful in future research on the involvement of antioxidant enzymes other than ROS in IR injury and to better understand other molecular effects associated with the damage that arises from IR.

Ethics Committee Approval: This study was approved by the University Animal Ethical Committee (ID: 2015/19).

Peer-review: Internally peer-reviewed.

Authorship Contributions: Concept: A.P., L.T.; Design: A.P., L.T.; Supervision: S.K., A.Ö.; Fundings: A.P.; Materials: A.P., L.T.; Data: G.D., M.K.C.; Analysis: A.P., B.E., A.Y.; Literature search: T.M., G.D.; Writing: A.P., T.M.; Critical revision: G.D., M.K.C.

\section{Conflict of Interest: None declared.}

Financial Disclosure: The authors declared that this study has received no financial support.

\section{REFERENCES}

1. Okada M, Falcão LFR, Ferez D, Martins JL, Errante PR, Rodrigues FSM, et al. Effect of atenolol pre-treatment in heart damage in a model of intestinal ischemia-reperfusion. Acta Cir Bras 2017;32:964-72. [CrossRef]

2. Feinman R, Deitch EA, Watkins AC, Abungu B, Colorado I, Kannan $\mathrm{KB}$, et al. HIF-1 mediates pathogenic inflammatory responses to intestinal ischemia-reperfusion injury. Am J Physiol Gastrointest Liver Physiol 2010;299:G833-43. [CrossRef]

3. Xing D, Zhang R, Li S, Huang P, Luo C, Hei Z, et al. Pivotal role of mast cell carboxypeptidase $\mathrm{A}$ in mediating protection against small intestinal ischemia-reperfusion injury in rats after ischemic preconditioning. J Surg Res 2014;192:177-86. [CrossRef]

4. Muñoz-Abraham AS, Patrón-Lozano R, Narayan RR, Judeeba SS, Alkukhun A, Alfadda TI, et al. Extracorporeal Hypothermic Perfusion Device for Intestinal Graft Preservation to Decrease Ischemic Injury During Transportation. J Gastrointest Surg 2016;20:313-21. [CrossRef]

5. Lv X, Wang ZM, Huang SD, Song SH, Wu FX, Yu WF. Emulsified isoflurane preconditioning reduces lung injury induced by hepatic ischemia/reperfusion in rats. Int J Med Sci 2011;8:353-61. [CrossRef]

6. Cho SSC, Rudloff I, Berger PJ, Irwin MG, Nold MF, Cheng W, et al. Remifentanil ameliorates intestinal ischemia-reperfusion injury. BMC Gastroenterol 2013;13:1-9. [CrossRef]

7. Abou-Zeid SM, El-bialy BE, El-borai NB, Abubakr HO, Elhadary AMA. Radioprotective effect of Date syrup on radiation- induced damage in Rats. Sci Rep 2018;1-10. [CrossRef]

8. Ikeda H, Suzuki Y, Suzuki M, Koike M, Tamura J, Tong J, et al. Apoptosis is a major mode of cell death caused by ischaemia and ischaemia/ reperfusion injury to the rat intestinal epithelium. Gut 1998;42:530-7.

9. Noda T, Iwakiri R, Fujimoto K, Matsuo S, Aw TY. Programmed cell death induced by ischemia-reperfusion in rat intestinal mucosa. Am J Physiol Gastrointest Liver Physiol 1998;274:G270-6. [CrossRef]

10. Cho HJ, Lee WH, Hwang OMH, Sonntag WE, Lee YW. Role of NADPH oxidase in radiation-induced pro-oxidative and pro-inflammatory pathways in mouse brain. Int J Radiat Biol 2017;93:1257-66.

11. Reliene R, Pollard JM, Sobol Z, Trouiller B, Gatti RA, Schiestl RH. $\mathrm{N}$-acetyl cysteine protects against ionizing radiation-induced DNA damage but not against cell killing in yeast and mammals. Mutat Res 2009;665:37-43. [CrossRef]

12. Pascher A, Klupp J, Langrehr JM, Neuhaus P. Anti-TNF-alpha therapy for acute rejection in intestinal transplantation. Transplant Proc 2005;37:1635-6. [CrossRef]

13. Cury DH, Costa JE, Irika K, Mijji L, Garcez A, Buchiguel C, et al. Protective effect of octreotide and infliximab in an experimental model of indomethacin-induced inflammatory bowel disease. Dig Dis Sci 2008;53:2516-20. [CrossRef]

14. Kostopanagiotou G, Avgerinos ED, Markidou E, Voiniadis P, Chondros $\mathrm{C}$, Theodoraki $\mathrm{K}$, et al. Protective effect of NAC preconditioning against ischemia-reperfusion injury in piglet small bowel transplantation: effects on plasma TNF, IL-8, hyaluronic acid, and NO. J Surg Res 2011;168:301-5. [CrossRef]

15. Pergel A, Kanter M, Yucel AF, Aydin I, Erboga M, Guzel A. Anti-inflammatory and antioxidant effects of infliximab in a rat model of intestinal ischemia/reperfusion injury. Toxicol Ind Health 2011;28:923-32.

16. Brekke OH, Sandlie I. Therapeutic antibodies for human diseases at the dawn of the twenty-first century. Nat Rev Drug Discov 2003;2:52-62.

17. Sakthiswary R, Syahrul Sazliyana S, Mohd Shahrir MS, Shahril NS, Hussein H. Beyond the joints in rheumatoid arthritis: Effects of adalimumab on hematologic and lipid indices. Excli J 2012;11:142-9.

18. Cure E, Cure MC, Tumkaya L, Kalkan Y, Aydin I, Kirbas A, Yilmaz A, Yuce S, Gokce MF. Topiramate ameliorates abdominal aorta cross-clamping induced liver injury in rats. Saudi J Gastroenterol 2014;20:297-303. 
19. Kurt A, Tumkaya L, Kalkan Y, Turut H, Cure MC, Cure E, et al. Is adalimumab protective in ischemia-reperfusion injury in lung? Iran J Basic Med Sci 2015;18:1093-9.

20. Cure MC, Cure E, Kalkan Y, Tumkaya L, Aydin I, Kirbas A, et al. The Protective Effect of Adalimumab on Renal Injury in a Model of Abdominal Aorta Cross-Clamping. Adv Clin Exp Med 2016;25:219-26.

21. Draper HH, Hadley M. Malondialdehyde determination as index of lipid peroxidation. Methods Enzymol 1990;186:421-31. [CrossRef]

22. Mercantepe T, Tumkaya L, Celiker FB, Topal Suzan Z, Cinar S, Akyildiz $\mathrm{K}$, et al. Effects of gadolinium-based MRI contrast agents on liver tissue. J Magn Reson Imaging 2018;48:1367-74. [CrossRef]

23. Chiu CJ, McArdle AH, Brown R, Scott HJ, Gurd FN. Intestinal mucosal lesion in low-flow states. I. A morphological, hemodynamic, and metabolic reappraisal. Arch Surg 1970;101:478-83. [CrossRef]

24. Mercantepe T, Unal D, Tümkaya L, Yazici ZA. Protective effects of amifostine, curcumin and caffeic acid phenethyl ester against cisplatin-induced testis tissue damage in rats. Exp Ther Med 2018;15:3404-12.

25. Juel IS, Solligård E, Lyng O, Strømholm T, Tvedt KE, Johnsen H, et al. Intestinal injury after thoracic aortic cross-clamping in the pig.J Surg Res 2004;117:283-95. [CrossRef]

26. Savary G, Lidouren F, Rambaud J, Kohlhauer M, Hauet T, Bruneval P, et al. Argon attenuates multiorgan failure following experimental aortic cross-clamping. Br J Clin Pharmacol 2018;84:1170-9. [CrossRef]

27. Ohkawa $\mathrm{H}$, Ohishi N, Yagi K. Assay for lipid peroxides in animal tissues by thiobarbituric acid reaction. Anal Biochem 1979;95:351-8. [CrossRef]

28. Cuzzocrea S, Mazzon E, Costantino G, Serraino I, Sarro A De, Caputi
AP. Effects of $\mathrm{n}$-acetylcysteine in a rat model of ischemia and reperfusion injury. Cardiovasc Res 2000;47:537-48. [CrossRef]

29. Zhan L, Zhang Y, Su W, Zhang Q, Chen R, Zhao B, et al. The Roles of Autophagy in Acute Lung Injury Induced by Myocardial Ischemia Reperfusion in Diabetic Rats. J Diabetes Res 2018;2018:5047526.

30. Sun Y, Lian M, Lin Y, Xu B, Li Y, Wen J, et al. Role of p-MKK7 in myricetin-induced protection against intestinal ischemia/reperfusion injury. Pharmacol Res 2018;129:432-42. [CrossRef]

31. Gordeeva AE, Sharapov MG, Tikhonova IV, Chemeris NK, Fesenko EE, Novoselov VI, et al. Vascular Pathology of Ischemia/Reperfusion Injury of Rat Small Intestine. Cells Tissues Organs 2017;203:353-64.

32. Neirynck N, Glorieux G, Schepers E, Dhondt A, Verbeke F, Vanholder R. Pro-inflammatory cytokines and leukocyte oxidative burst in chronic kidney disease: culprits or innocent bystanders?. Nephrol Dial Transplant 2015;30:943-51. [CrossRef]

33. Shaki F, Ashari S, Ahangar N. Melatonin can attenuate ciprofloxacin induced nephrotoxicity: Involvement of nitric oxide and TNF- $\alpha$. Biomed Pharmacother 2016;84:1172-8. [CrossRef]

34. Shen C, Assche GV, Colpaert S, Maerten P, Geboes K, Rutgeerts P, et al. Adalimumab induces apoptosis of human monocytes: a comparative study with infliximab and etanercept. Aliment Pharmacol Ther 2005;21:251-8. [CrossRef]

35. Ossendorff R, Grad S, Stoddart MJ, Alini M, Schmal H, Südkamp N, et al. Autologous Chondrocyte Implantation in Osteoarthritic Surroundings: TNF $\alpha$ and Its Inhibition by Adalimumab in a Knee-Specific Bioreactor. Am J Sports Med 2018;46:431-40. [CrossRef]

\title{
DENEYSEL ÇALIŞMA - ÖZET
}

\section{İnfrarenal aort oklüzyonu ile oluşan intestinal hasarında adalimumab'ın koruyucu etkisi}

\section{Dr. Ahmet Pergel,, ${ }^{1}$ Dr. Levent Tumkaya, ${ }^{2}$ Dr. Gökhan Demiral, ${ }^{1}$ Dr. Muhammet Kadri Çolakoğlu, ${ }^{1}$} Dr. Süleyman Kalcan, ${ }^{1}$ Dr. Ali Özdemir, ${ }^{1}$ Dr. Tolga Mercantepe, ${ }^{2}$ Dr. Başar Erdivanlı, ${ }^{3}$ Dr. Adnan Yılmaz ${ }^{4}$

\author{
${ }^{1}$ Recep Tayyip Erdoğan Üniversitesi Tip Fakültesi, Genel Cerrahi Anabilim Dalı, Rize \\ ${ }^{2}$ Recep Tayyip Erdoğan Üniversitesi Tip Fakültesi, Histoloji ve Embriyoloji Anabilim Dalı, Rize \\ ${ }^{3}$ Recep Tayyip Erdoğan Üniversitesi Tip Fakültesi, Anestezi ve Reaminasyon Anabilim Dalı, Rize \\ ${ }^{4}$ Recep Tayyip Erdoğan Üniversitesi Tip Fakültesi, Biyokimya Anabilim Dalı, Rize
}

AMAÇ: Çeşitli cerrahi ve organ transpalantasyonu, strangüle herniasyonlar ve neonatal nekrotizan enterokolit gibi klinik durumlarda ortaya çıkan intestinal iskemi reperfüzyon (I/R) hasarı cerrahi yoğun bakım ünitelerindeki ölümlerin en başlıca sebebini oluşturur. İskemi-reperfüzyon (IR) neden olduğu bağırsak hasarında oksidatif stresin rol oynadığı bildirilmesine rağmen kalıcı bir çözüm bulunamamışır. Bu çalışmada I/R neden olduğu ince bağırsak üzerindeki etkilerini moleküler düzeyde inceyerek, adalimumab (ADA) ve antioksidanların olası koruyucu potansiyelini geleceğe dönük ele aldık.

GEREÇ VE YÖNTEM: Toplam 24 erkek Sprague-Dawley sıçanlar rasgele olarak kontrol, iskemi/reperfüsion (I/R) ve I/R+ADA uygulama grubu olmak üzere üç gruba ayrıldı.

BULGULAR: I/R grubunda ince bağırsak dokusunda GSH seviyesinde bir değişiklik gözlemlenmemekle beraber MDA seviyesini ve kaspaz-3 pozitif enterositlerin sayısal yoğunluğunu artırdığını gözledik (sırasıyla, $p=0.00 ; p=0.00$ ). Bunun yanında villus kripta yapılarında dejenerasyona neden olduğunu saptatık. ADA tedavisinin I/R grubuna kıyasla MDA seviyesini ve kaspaz-3 pozitif enterositlerin sayısal yoğunluğunu azalttığııı gözlemledik (sırasıyla, $p=0.00 ; p=0.011$ ).

TARTIŞMA: Adalimumab, I/R neden olduğu intestinal hasarın önlenmesinde yararlı olabilir.

Anahtar sözcükler: Adalimumab; iskemi; intestinal hasar; oksidatif stress; reperfüzyon; sıçan.

Ulus Travma Acil Cerrahi Derg 2020;26(3):366-372 doi: 10.14744/tites.2019.59607 